\title{
Invasion of Varroa jacobsoni into drone brood cells of the honey bee, Apis mellifera
}

\author{
WJ Boot 1,2, J Schoenmaker 2, JNM Calis 1,2, J Beetsma ${ }^{2}$ \\ 1 Department of Pure and Applied Ecology, Section Population Biology, \\ University of Amsterdam, Kruislaan 320, 1098 SM Amsterdam; \\ 2 Department of Entomology, Wageningen Agricultural University, POB 8031, \\ 6700 EH Wageningen, The Netherlands
}

(Received 23 September 1994; accepted 16 January 1995)

\begin{abstract}
Summary - Invasion of Varroa mites into drone brood cells of honey bees was studied in colonies without worker brood. The probability for a mite to invade was dependent on the brood/bees ratio, which is defined as the number of drone brood cells capped per $\mathrm{kg}$ of bees. When compared with invasion in colonies with exclusively worker cells, Varroa mites invaded drone cells 11.6 times more frequently. This suggests that the biased distribution of mites over drone and worker cells in colonies with both types of brood cells results predominantly from the higher rate of invasion into a drone cell per se, when compared to that into a worker cell per se. Since the rate of invasion is high in drone cells, a trapping method using drone combs may be very effective in controlling the Varroa mite. When no other brood is present, 462 drone cells are estimated to be sufficient to trap $95 \%$ of the mites in a colony of $1 \mathrm{~kg}$ of bees.
\end{abstract}

Apis mellifera / Varroa jacobsoni / biotechnical control / invasion behaviour / drone cell

\section{INTRODUCTION}

The parasitic mite Varroa jacobsoni Oudemans is a harmful pest of the western honey bee, Apis mellifera L, worldwide. It parasitizes both adult and immature bees, but reproduction of the mites only occurs inside capped drone and worker brood cells (Ifantidis and Rosenkranz, 1988). More adult offspring are produced in drone cells compared to worker cells (eg. Fuchs and Langenbach, 1989). Therefore, one might expect that mites prefer drone brood over worker brood. Indeed, about 8 times more mites are generally found per cell in drone cells than in worker cells (eg, Fuchs, 1990; reviewed in Fries et al, 1994). In addition, mites prefer drone larvae to worker larvae when given the choice in laboratory tests (Rosenkranz et al, 1984; Otten and Fuchs, 1988; Le Conte et al, 1989).

Recently, Boot et al (1994a) showed that the rate of invasion into worker cells (number of mites that invade per day) depends on the ratio of worker brood cells to adult bees: the brood/bees ratio (number of brood cells capped per day and per $\mathrm{kg}$ of bees). The larger the brood/bees ratio, the higher the 
rate of invasion. This may be understood as follows. A mite has to be carried close to a brood cell by a bee before invasion occurs (Boot et al, 1994b), and only some of the honey bees in a colony reside near a cell suitable for mite invasion. Therefore, the number of bees that bring a mite close enough to a brood cell may determine how many mites invade, and this number of bees will increase when there are more brood cells present per bee, ie a higher brood/bees ratio (Boot et al, 1994a).

The higher number of mites found in drone cells compared to worker cells (Fuchs, 1990) may result from a higher rate of invasion into a drone brood cell per se, compared with a worker brood cell per se. This higher rate of invasion may have a number of causes. Firstly, drone brood cells are susceptible to invasion for a period 2-3 times longer than worker brood cells (Ifantidis, 1988; Boot et al, 1992). Hence, the chance for a mite on a bee to come close enough to a suitable brood cell is increased accordingly. Secondly, the surface of a drone cell is 1.7 times larger than that of a worker cell, which also increases the chance for a mite on a bee to come close enough to a suitable brood cell. Thirdly, the presence of a drone larva instead of a worker larva may increase the rate of invasion. This may occur when a signal coming from drone larvae evokes a stronger response to invade than a corresponding signal from worker larvae. Alternatively, the behaviour of the bees may be affected by the presence of either drone or worker larvae in such a way that the rate of invasion is also affected.

The biased distribution of mites over drone and worker cells may also arise because the mites refrain from invading worker cells when the drone cells are nearby. If so, then the presence of drone cells will negatively affect invasion into worker cells. Consequently, the difference between the rate of invasion into a drone cell per se and that into worker cell per se, will be too small to explain the biased distribution of mites when both cell types are present.

In this paper, the rate of invasion into drone cells is determined for 2 reasons. Firstly, it is compared with the rate of invasion into worker cells to test whether the difference between these rates is large enough to explain the biased distribution of the mites. Secondly, it is determined because it is a valuable parameter for development of Varroa control methods that utilize trapping of mites in drone combs.

\section{MATERIALS AND METHODS}

\section{Experimental set-up}

The rate of invasion into drone cells was studied in the Netherlands in 6 colonies of the western honey bee, $A$ mellifera. A similar set-up was used as in earlier experiments to determine the rate of invasion into worker cells (Boot et al, 1994a).

The experimental colonies were moved to an isolated place, at least $1 \mathrm{~km}$ away from other bee colonies, to prevent exchange of mites between experimental and other bee colonies (Sakofsk and Koeniger, 1988; Rademacher et al, 1989). All brood was removed from the colonies and most of the mites that were already present on the bees were killed with 2 treatments of $20 \mathrm{ml}$ $85 \%$ formic acid applied on pieces of cardboard (Wachendîrfer et al, 1985; Fries, 1989). Ample honey and pollen stores were available in the experimental colonies.

Every day a comb with about 50 drone larvae was placed into the colonies. These drone larvae were 3-4 d old, dated according to the method of Boot and Calis (1991). In the colonies that were used for brood dating, drone comb and worker comb were alternately offered for oviposition. When only drone comb was offered for oviposition, the queen started to lay worker eggs into the drone cells within a few days. In the experimental colonies, the queen was allowed to oviposit freely, and therefore combs with eggs had to be removed regularly to keep the colonies free of brood other than the 50 drone cells introduced daily. After 1 week, it was assumed that the bees in the experimental colonies had adapted 
to nurse the number of drone larvae introduced. Subsequently, a group of mites was introduced by placing brood combs with emerging bees heavily infested by mites into the colonies. After 1-2 d, these combs were removed again. To monitor invasion of the mites that had been introduced in this way, the capping of the drone cells was monitored daily by placing transparent sheets over the brood area and by marking capped cells. After capping of the cells, the comb was removed from the colony, cells were opened, and the number of mites per cell was counted.

Invasion of mites into drone cells was monitored at intervals of $1 \mathrm{~d}$ during a period of 5-9 d. At the end, mites still on the bees were killed by two $1 \mathrm{ml}$ applications of Perizin $\left.{ }^{(}\right)$(Bayer; active ingredient: coumaphos) in $49 \mathrm{ml}$ water. The dead mites, which had fallen through the gauze bottom of the hive into a drawer, were then counted. After the second application of Perizin ${ }^{\otimes}$ hardly any dead mites were found and it was assumed that all mites were killed. Subsequently, the actual size of the bee population ( $\mathrm{kg}$ of bees) during the experiments was estimated by weighing the hive with the experimental colony and subtracting the weight of the hive and combs, after bee removal.

\section{Statistical analysis}

The rate of invasion into drone cells was assumed to depend on the number of mites present on the bees and the probability of invasion. The number of mites present on the bees at the beginning of each time interval was estimated by summing the mites found in all drone cells that were capped after that moment and the number of mites remaining on the bees at the end of the experiment. Subsequently, the probability of drone-cell invasion was calculated for each interval by dividing the number of mites found in drone cells that were capped in a certain interval by the estimate of mites on bees at the start of that interval. A logit link-function was used to model the probability of invasion, which was assumed to depend on the number of drone cells capped during a time interval per $\mathrm{kg}$ bees (brood/bees ratio) and the index of time (Boot et al, 1994a):

$$
\begin{gathered}
P_{t}=\left\{1+\exp \left(-L_{t}\right)\right\}^{-1} \\
L_{t}=\beta_{0}+\beta_{1}[\text { brood/bees ratio }]_{t}+\beta_{2} t
\end{gathered}
$$

where $t$ is the index of time, indicating the number of time intervals of one day, $P_{t}$ is the probability of invasion into drone cells capped during time interval $t, L_{t}$ is the logit of $P_{t}$, and [brood/bees ratio] $]_{t}$ is the number of drone cells capped during $t$ per $\mathrm{kg}$ bees. The parameters $\beta_{0}, \beta_{1}$ and $\beta_{2}$ were estimated by multiple regression, using maximum likelihood estimation (SAS Institute Inc, 1989).

\section{Comparison of the rate of invasion into drone cells with that into worker cells}

When the probability of invasion per unit of time $(t)$ is constant, the number of mites on bees $(M)$ show a negative exponential decay:

$$
M_{t}=M_{0} e^{-r t}
$$

where $r$ is the relative rate of invasion $\left(d^{-1}\right)$. This relative rate of invasion was used to compare invasion into drone cells with that into worker cells by assuming a linear function through the origin, providing the relationship between the number of brood cells capped during a time interval per $\mathrm{kg}$ of bees (brood/bees ratio) and $r$. For each time interval, $r$ was estimated from the probabilities of invasion found for drone cells (this study) and found for worker cells (Boot et al, 1994a) using the following equation:

$$
r=-\ln \left(M_{t+1} / M_{t}\right)=-\ln \left(1-P_{t}\right)
$$

where $t$ is the index of time, which indicates the number of time intervals of $1 \mathrm{~d}, M_{t}$ is the number of mites on bees at the beginning of time interval $t$, and $P_{t}$ is the probability of invasion during time interval $t$.

\section{RESULTS}

Data on invasion into drone cells are shown in table I. Drone brood proved to be very effective in trapping the mites present on adult bees. Daily introduction of about 50 drone cells over 5-9 d led to invasion of a substantial part of the mites introduced: $80-94 \%$ of the mites invaded into $175-459$ drone cells.

Invasion into drone cells was more precisely studied per time interval (Boot et al, 1994a), using multiple regression on the 
Table I. Data from the experiments to study the rate of invasion into drone cells by Varroa mites.

Introduction date

Number of time intervals of $1 d$

Average number of drone cells capped per time interval

Size of bee populationa

( $\mathrm{kg}$ bees)

Total number of mites ${ }^{b}$

Total number of mites invaded (\% in parentheses)

Colony number

$\begin{array}{llllll}1 & 2 & 3 & 4 & 5 & 6\end{array}$

$\begin{array}{cccccc}28-5-92 & 28-5-92 & 13-6-92 & 13-6-92 & 9-7-92 & 9-7-92 \\ 5 & 5 & 7 & 7 & 9 & 9 \\ 46 \pm 21 & 35 \pm 16 & 54 \pm 21 & 53 \pm 20 & 51 \pm 28 & 31 \pm 16 \\ 0.659 & 0.473 & 2.233 & 1.475 & 1.319 & 1.022 \\ 40 & 92 & 480 & 524 & 417 & 630 \\ 33(83) & 77(84) & 385(80) & 473(90) & 392(94) & 541(86)\end{array}$

a The size of the bee population was estimated by weighing the bees at the end of the experiments. ${ }^{b}$ The total number of mites was calculated by summing the mites that had invaded the drone cells and the mites that had remained on the bees after the experiment.

probability of invasion, $P_{t}$, whereas $P_{t}$ was assumed to depend on the brood/bees ratio (number of drone cells capped during $1 \mathrm{~d}$ per $\mathrm{kg}$ bees), and the time since introduction of the mites (table II). The data of all experiments were used for statistical analysis. $P_{t}$ was positively correlated with the brood/bees ratio, whereas the time elapsed since the introduction of the mites had no effect on $P_{t}$. Figure 1 shows the relationship found between the brood/bees ratio and the probability of invasion per day.

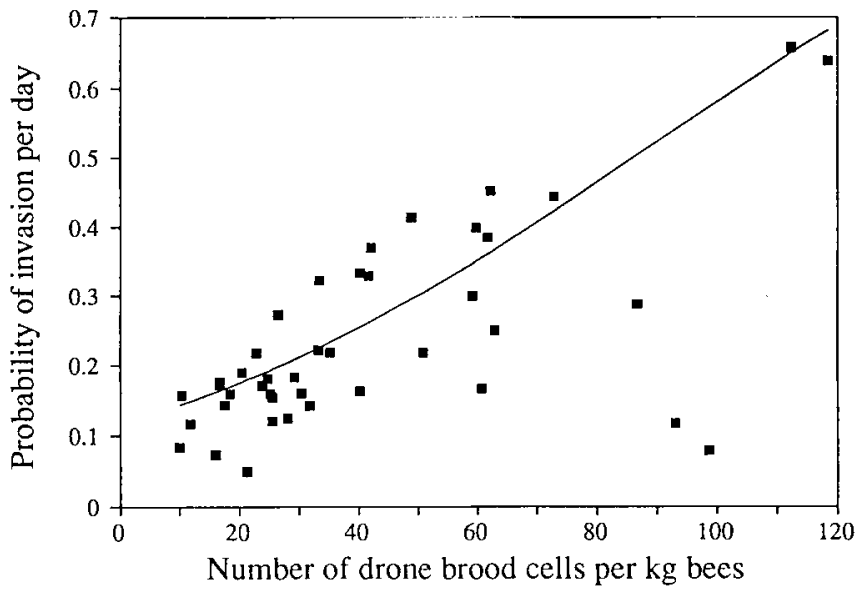

Fig 1. Relationship between the brood/bees ratio and the probability of invasion per day. The line has been drawn using the parameters from table 11: $\operatorname{Logit}(P)=$ $0.0235 \cdot[\mathrm{brood} / \mathrm{bees}$ ratio], where $P$ is the probability of invasion and [brood/bees ratio] is the number of drone cells per $\mathrm{kg}$ of bees. Data points; - calculated from model. 
Fig 2. Comparison of the reiative invasion rate into drone cells $(\boldsymbol{D})$ and that into worker cells $(0)$ in relation to the number of brood cells per $\mathrm{kg}$ of bees.

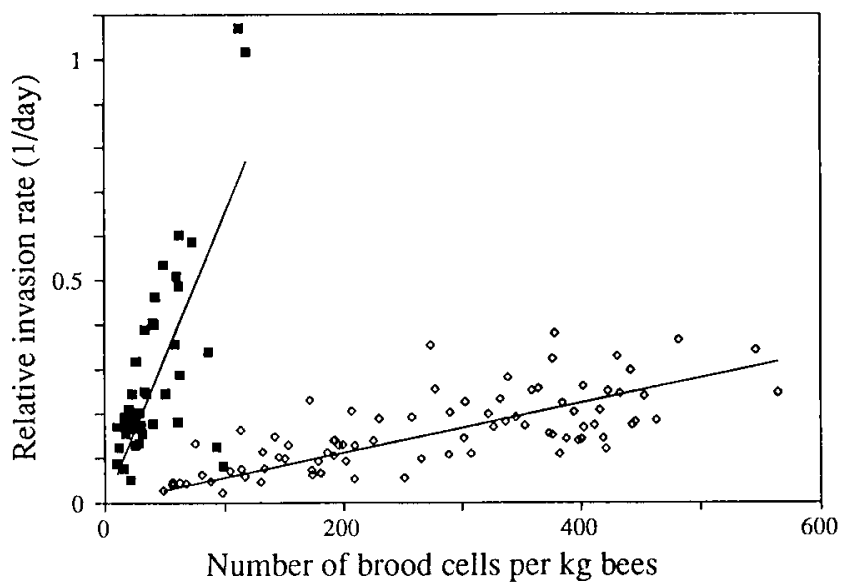

In case of equal brood/bees ratios, the rate of invasion into drone cells was much higher than that into worker cells (fig 2). The relationships between the relative rate of invasion and the brood/bees ratio per day were described by:

$r_{\mathrm{d}}\left(\mathrm{d}^{-1}\right)=0.00649(\mathrm{~kg}$ bees $/$ number of cells capped) $\cdot[\mathrm{brood} / \mathrm{bees}$ ratio] (number of cells capped/(kg bees-day)), for drone brood cells $r_{w}=0.00056 \cdot[$ brood/bees ratio], for worker brood cells

Thus, Varroa mites invaded drone cells 11.6 times more frequently than worker cells.

\section{DISCUSSION}

Similar to invasion into worker cells (Boot et al, 1994a), the logit of $P_{t}$ was proportional to the brood/bees ratio (table II; fig 1), although our data show a high variation in $P_{t}$ which may result from the strong manipulation of colonies before the experiments and the daily disturbance of colonies during the experiments. The probability for a mite to invade a drone cell was much higher than the probability of invading a worker cell. Part of this higher frequency of invasion may be due to the $2-3$ times longer period of attractiveness of drone cells (Ifan-

Table II. Multiple regression of the brood/bees ratio (number of drone ceils that were capped during 1 $\mathrm{d}$ per $\mathrm{kg}$ of bees) and the index of time which indicates the number of time intervals of $1 \mathrm{~d}, t$, on the probabilty of invasion, $P_{t}$ : Logit $\left(P_{t}\right)=\beta_{0}+\beta_{1}[$ brood/bees ratio $] \mathrm{t}+\beta_{2} t$.
Model
$\beta_{0}$
$\beta_{1}$
$\beta_{2}$
$\beta_{0}+\beta_{1}[\text { brood/bees ratio }]_{t}$
$-2.02$
$0.0235^{\star \star \star}$
$\beta_{0}+\beta_{1}[\text { brood/bees ratio }]_{t}+\beta_{2} t$
$-1.94$
$0.0233^{\star \star \star}$
$N S=$ not significant. ${ }^{\star \star \star}=P<0.001$. 
tidis, 1988; Boot et al, 1992). When invasion in a cell depends on the frequency that a bee brings a mite close enough to invade, the number of mites that invade per cell is also expected to be 2-3 times higher, provided that the number of mites on the bees stays the same. In addition, when the frequency that a bee brings a mite close enough for invasion is proportional to the surface of a brood cell, 1.7 times more mites are expected per drone cell due to their 1.7 times larger surface. Combining these factors would result in 3.4-5.1 times more frequent invasion into drone cells than into worker cells. However, an 11.6 times higher frequency was found. Thus, invasion into drone cells is probably increased further due to the presence of a drone larva instead of a worker larva in the cell.

In a colony of a given size, $r$ is constant per cell. When both drone and worker cells are available for mite invasion, and assuming that invasion into drone and worker cells are independent, the number of mites on adult bees decreases as follows:

$$
d M / d t=-\left(r_{\mathrm{d}}+r_{\mathrm{w}}\right) M
$$

where $M$ is the number of mites on bees, $t$ is time (d), $r_{d}$ is the relative rate of invasion in drone cells $\left(\mathrm{d}^{-1}\right)$, and $r_{w}$ is the relative rate of invasion in worker cells $\left(d^{-1}\right)$. Because mites invading drone cells and mites invading worker cells both come from the same pool of mites on adult bees, $M$, the ratio of $r_{d}$ per cell to $r_{w}$ per cell is equal to the ratio of mites found per drone cell to their number found per worker cell (see Appendix). Hence, 11.6 times more mites are expected per drone cell than per worker cell, which is even more than the actual distribution of about 8 times more mites per drone cell on average, albeit with a high variation. This suggests that differences in $r$ are the most important cause of the biased distribution over drone and worker cells. Under the alternative hypothesis that mites refrain from invasion into worker cells when drone cells are nearby, one would expect a smaller ratio of $r_{\mathrm{d}}$ per cell to $r_{w}$ per cell than 8:1, because $r_{d}$ and $r_{w}$ were determined in a situation with exclusively drone and exclusively worker brood, respectively. Hence, our results suggest that the mites do not refrain from invasion into worker cells when drone cells are nearby, although the hypothesis that mites do refrain from invasion into worker cells cannot be entirely excluded.

In studies of the distribution of mites over drone and worker cells, a large variation is found in the ratio between the number of mites per drone cell and that per worker cell. Fuchs (1990) found ratios ranging from 0.94 to 30.6 in 68 replicates, whereas Calis et al (1993) found ratios of 7.7 and 15.3 in 2 replicates. This high variation may occur because drone and worker cells are never attractive to mites during exactly the same period, and because the number of mites that reside on the bees in a honey bee colony varies strongly over time, due to invasion of the mites into open brood cells and emergence of mites from capped cells. Alternatively, Fuchs $(1990,1992)$ argued that mites may vary with respect to an acceptance threshold for worker cells, which may thus result in a variable distribution over drone and worker cells.

Although the variation in the ratio of the number of mites per drone cell to the number of mites per worker cell is high, studies concerning the distribution over drone and worker cells have shown an average ratio of about 8 . Fuchs (1990) found an average ratio of 8.3, whereas Schulz (1984) and Sulimanovic et al (1982) reported ratios of 8.6 and 7.2 , respectively. These values are well below the ratio of 11.6, expected for the ratio of $r_{\mathrm{d}}$ per cell to $r_{\mathrm{w}}$ per cell. This may occur because invasion into drone cells and invasion into worker cells is more or less segregated in time, and because the number of mites on the bees may varies strongly during the period in which a certain cell is attractive to the mites. When many mites invade, the mites on bees probably deplete 
quickly, and fewer mites will invade a cell that is attractive at that time than expected if more mites were present on the bees. Since $r$ is so much higher per drone cell than per worker cell, the number of mites on bees will deplete much quicker during periods when drone cells are attractive and therefore the distribution over drone and worker cells may become less biased. Such an effect is expected to be stronger when the proportion of drone cells versus worker cells is higher, and indeed Fuchs (1990) found a less biased distribution with a higher proportion of drone cells.

\section{Trapping of mites in drone cells as a biotechnical control method}

Since the rate of invasion into drone cells is high, trapping mites in drone brood is a useful biotechnical method to control the Varroa mite (Schulz et al, 1983; Rosenkranz and Engels, 1985). Currently, trapping of mites in drone brood is applied in colonies with normally developing brood nests. This will decrease the effectiveness of the trapping method, because in normal colonies about $80 \%$ or more of the brood consists of worker brood (Page and Metcalf, 1984; Rowland and McLellan, 1987) and therefore a substantial part of the mites will invade worker cells. Additionally, mites may invade drone cells that are not removed from the colonies. A drone cell trapping method will be much more effective when it is applied during periods when no brood other than that introduced for trapping is present in the colony. Following the model behind the regression line from figure 2 , which implies that the percentage of mites trapped per day only depends on the number of capped cells in a colony with constant size, our results show that to reach a $95 \%$ trapping effectiveness per day, a relative invasion rate of $-\ln (0.05)=3.00 d^{-1}$ is needed. If so, only $3.00\left(\mathrm{~d}^{-1}\right) / 0.00649(\mathrm{~kg}$ bees/number of cells capped) $=462$ drone cells are needed to trap $95 \%$ of the mites in a colony of $1 \mathrm{~kg}$ bees per day. The trapping of mites in drone brood can therefore be an effective non-chemical method to control Varroa mites in honey bee colonies.

\section{ACKNOWLEDGMENTS}

We thank MW Sabelis, JC van Lenteren, M Dicke and $A$ de Ruijter for their critical comments on earlier drafts of the manuscript and G Gort for the statistical analysis of the data. This study was supported by the Technology Foundation (STW), grant number: WGB88.1512

\section{APPENDIX}

When both drone and worker cells are available for mite invasion, and when invasion into drone and worker cells are independent, the number of mites on adult bees decreases as follows:

$$
d M / d t=-\left(r_{\mathrm{d}}+r_{\mathrm{w}}\right) M
$$

where $M$ is the number of mites on bees, $t$ is time (d), $r_{d}$ is the relative rate of invasion in drone cells $\left(\mathrm{d}^{-1}\right)$, and $r_{\mathrm{w}}$ is the relative rate of invasion in worker cells $\left(d^{-1}\right)$.

In case of constant numbers of drone and worker cells available, $r_{\mathrm{d}}$ and $r_{\mathrm{d}}$ are also constant, and:

$$
M_{t}=M_{0} \mathrm{e}^{-\left(r_{\mathrm{d}}+r_{w}\right) t}
$$

while the number of mites that invade drone cells increases as follows:

$$
d M / d t=r_{\mathrm{d}} M
$$

Integration of $M$ over $t$ yields an expression, indicated by $M_{d, i}$ :

$$
M_{\mathrm{d}, t}=-r_{\mathrm{d}} /\left(r_{\mathrm{d}}+r_{\mathrm{w}}\right) \cdot M_{0}\left(\mathrm{e}^{-\left(r_{\mathrm{d}}+\mathrm{rw}_{\mathrm{w}}\right) t}-1\right)
$$

Similarly the number of mites that invade worker cells is:

$$
M_{\mathrm{w}, \mathrm{t}}=-r_{\mathrm{w}} /\left(r_{\mathrm{d}}+r_{\mathrm{w}}\right) \cdot M_{0}\left(\mathrm{e}^{-\left(r_{\mathrm{d}}+r_{\mathrm{w}}\right) t}-1\right)
$$


Thus,

$$
M_{\mathrm{d}, t} / M_{\mathrm{w}, t}=r_{\mathrm{d}} / r_{\mathrm{w}}=r_{1, \mathrm{~d}} N_{\mathrm{d}} / r_{1, \mathrm{w}} N_{\mathrm{w}}
$$

where $r_{1, \mathrm{~d}}$ and $r_{1, \mathrm{w}}$ are the relative rates of invasion per drone and per worker cell respectively, and $N_{\mathrm{d}}$ and $N_{\mathrm{w}}$ are the numbers of drone and worker cells. The ratio of mites per drone cell to their number per worker cell is then:

$$
\left(M_{\mathrm{d}, \mathrm{t}} / N_{\mathrm{d}}\right) /\left(M_{\mathrm{w}, \mathrm{t}} / N_{\mathrm{w}}\right)=r_{1, \mathrm{~d}} / r_{1, \mathrm{w}}=11.6
$$

Every small time step $t, N_{\mathrm{d}}$ and $N_{\mathrm{w}}$ can be considered constant and the ratio of mites per drone cell to their number per worker cell will be 11.6 in each time step, regardless of whether $N_{\mathrm{d}}$ and $N_{\mathrm{w}}$ vary between time steps.

\section{Résumé - Pénétration de Varroa jacob- soni Oud dans les cellules de couvain de mâles de l'abeille Apis mellifera L. Le} déroulement de la pénétration de l'acarien Varroa jacobsoni dans les cellules du couvain de mâles d' $A$ mellifera a été étudié sur 6 colonies. Chaque jour on a introduit dans les colonies un rayon comprenant 50 larves de mâles âgées de 3-4 j. Tout autre couvain a été ôté. Les varroas ont été introduits en plaçant des rayons de couvain fortement infesté avec des abeilles naissantes dans les colonies. Pour suivre la pénétration dans les cellules de couvain de mâles, on a noté chaque jour l'operculation des cellules de mâles. Les cellules de mâles parasitées ont été désoperculées et les acariens dénombrés. Au bout de 5 à 9 j les varroas encore présents sur les abeilles ont été tués par un traitement au Perizin ${ }^{\circledR}$ (1 $\mathrm{ml}$ dans $49 \mathrm{ml}$ d'eau, répété 2 fois). Les varroas morts tombés sur le fond de la ruche ont été dénombrés. Ensuite la population d'abeilles a été évaluée par pesage. Les données obtenues sont indiquées dans le tableau I. La pénétration dans les cellules de couvain de mâles a été étudiée avec plus de précision 1 j sur
2 en utilisant la régression multiple de la probabilité de l'invasion $P_{t}$. On a estimé que $P_{t}$ dépendait du rapport couvain/abeilles, qui est défini par le nombre de cellules de couvain operculées par $\mathrm{kg}$ d'abeilles et le temps écoulé depuis l'introduction des acariens (tableau II). Dans le cas de l'infestation des cellules d'ouvrières, la probabilité pour un acarien de pénétrer dans une cellule dépend aussi du rapport couvain/abeilles (fig 1). Mais la probabilité pour un acarien de pénétrer dans une cellule de mâles est beaucoup plus élevée que pour une cellule d'ouvrières. Pour un même rapport couvain/abeilles, les varroas infestent 11,6 fois plus souvent les cellules de mâles que les cellules d'ouvrières (fig 2). Lorsque dans une colonie les 2 types de cellules sont disponibles en quantités égales, on s'attend donc à une distribution inégale des varroas, basée sur la fréquence inégale de pénétration des cellules, les acariens étant 11,6 fois plus nombreux dans les cellules de mâles que dans celles d'ouvrières (appendice 1). Cette inégalité attendue est même supérieure à celle effectivement trouvée dans les colonies ayant les 2 types de cellules de couvain, qui est en moyenne de 8 fois en faveur des cellules de mâles. L'inégalité effective peut être inférieure à l'inégalité attendue parce que la pénétration dans les cellules d'ouvrières ou de mâles est, dans la colonie, plus ou moins séparée dans le temps. Puisque la fréquence de pénétration dans une cellule de mâles est 11,6 fois supérieure à celle d'une cellule d'ouvrières, le nombre d'acariens présents sur les abeilles baissera beaucoup plus rapidement durant les périodes où les cellules de mâles sont abondantes et l'inégalité réelle de distribution entre cellules de mâles et cellules d'ouvrières pourra en conséquence être moindre. En outre la distribution inégale s'explique suffisamment par la fréquence inégale de pénétration par cellule individuelle. II n'y a donc aucune raison de croire que les varroas réagissent à la présence voisine de cellules de couvain de 
mâles en s'abstenant de pénétrer dans les cellules de couvain d'ouvrières, provoquant ainsi une distribution inégale entre cellules de mâles et cellules d'ouvrières. Puisque le taux de pénétration dans les cellules de mâles est plus élevé, une méthode de piégeage à l'aide de rayons de couvain peut être efficace pour lutter contre l'acarien $V$ jacobsoni. En l'absence d'autre couvain, on peut estimer que 462 cellules de mâles permettent de piéger $95 \%$ des varroas dans une colonie de $1 \mathrm{~kg}$ d'abeilles.

\section{Apis mellifera / Varroa jacobsoni / com- portement parasite / pénétration cellule / lutte biotechnique / couvain mâle}

\section{Zusammenfassung - Der Verlauf des Eindringens von Varroa jacobsoni in Drohnenzellen der Honigbiene Apis mel-} lifera. Der Verlauf des Eindringens von Varroamilben in Drohnenzellen von Honigbienen wurde an 6 Bienenvölkern untersucht. Jeden Tag wurde eine Wabe mit etwa 50 Drohnenlarven im Alter von 3-4 Tagen in die Völker eingestellt. Die andere Brut wurde entfernt. Die Völker wurden durch Zufügen von stark varroabefallenen Brutwaben mit schlüpfenden Bienen infiziert. Zur Erfassung des Zeitverlaufs des Drohnenbrutbefalls wurde die Verdeckelung der Drohnenzellen täglich registriert. Die befallenen Drohnenzellen wurden geöffnet und die Anzahl von Milben in den Zellen gezählt. Nachdem der Brutzellenbefall 5-9 Tage lang erfasst worden war, wurden die noch auf den Arbeiterinnen verbliebenen Milben durch zwei Behandlungen mit $1 \mathrm{ml}$ Perizin in $49 \mathrm{ml}$ Wasser abgetötet und die auf die Bodeneinlagen gefallenen toten Milben gezählt. Danach wurde die Bienenpopulation durch Wiegen abgeschätzt. Die übergreifenden Versuchsdaten sind in Tabelle I gelistet. Der genauere Verlauf des Befalls der Drohnenzellen in Zeitabständen von jeweils einem Tag wurde durch Berechnung einer multiplen Regression untersucht. Hierbei wurde angenom- men, daß die Wahrscheinlichkeit des Brutbefalls, $\mathrm{Pt}$, von dem Verhältnis von Brut $\mathrm{zu}$ Bienen (definiert als die Anzahl verdeckelter Brutzellen pro kg Bienen) und der Zeit seit Hinzufügung der Milben abhängt (Tabelle II). Ähnlich wie beim Befall von Arbeiterinnenzellen war die Wahrscheinlichkeit, mit der eine Milbe eine Drohnenbrutzelle befällt, von dem Verhältnis von Brut zu Bienen abhängig (Abb 1), allerdings war sie erheblich höher als bei Arbeiterinnenbrutzellen. Varroamilben befallen Drohnenzellen 11,6 mal häufiger als Arbeiterinnenbrutzellen (Abb 2). Als Ergebnis der unterschiedlichen Befallshäufigkeit der Zellen kann daher enwartet werden, daß bei gleichzeitiger Verfügbarkeit von Drohnen- und Arbeiterinnenzellen eine ungleiche Verteilung der Milben mit 11,6 mal höherem Befall der Drohnenzellen resultiert (Appendix). Diese erwartete Ungleichheit ist sogar höher als die tatsächlich in Völkern mit beiden Bruttypen gefundene, bei der im Mittel ein etwa 8 mal höherer Befall pro Drohnenbrutzelle im Vergleich zu Arbeiterinnenzellen ermittelt wurde. Die tatsächliche Ungleichheit könnte dadurch weniger ausgeprägt als die theoretisch erwartete sein, daß in normalen Bienenvölkern der Befall von Drohnen- und Arbeiterinnenzellen mehr oder weniger zeitlich getrennt stattfindet. Da die Häufigkeit des Befalls einer Drohnenzelle 11,6 mal größer ist als die der Arbeiterinnen, wird in Zeiten reichlicher Verfügbarkeit von Drohnenzellen die Anzahl der Milben auf den Bienen erheblich rascher vermindert. Die tatsächliche Verteilung der Milben auf die Bruttypen könnte daher weniger ungleich sein. Zusätzlich reicht die unterschiedliche Befallshäufigkeit pro Zeiteinheit völlig zur Erklärung des unterschiedlichen Befalls aus. Es besteht daher kein Anlass für die Annahme, daß sich die Milben vom Befall einer Arbeiterinnenzelle zurückhalten, falls benachbarte Drohnenbrutzellen vorhanden sind, und daß die ungleiche Verteilung hierdurch verursacht wird. Da die Rate des Drohnenbrutzellenbefalls hoch ist, könnte eine Fangmethode 
unter Benutzung von Drohnenwaben eine sehr wirksame Bekämpfungsmaßnahme gegen Varroamilben darstellen. Falls keine weitere Brut vorhanden ist, wären nach unserer Abschätzung 462 Drohnenbrutzellen ausreichend um $95 \%$ der Milben in einem Bienenvolk mit $1 \mathrm{~kg}$ Arbeiterinnen einzufangen.

\section{Apis mellifera / Varroa jacobsoni / Ein- dringensverhalten / biotechnische Bekämpfung / Drohnenzelle}

\section{REFERENCES}

Boot WJ, Calis JNM (1991) A method to obtain dated brood in honeybee colonies. Bee World 72, 19-21

Boot WJ, Calis JNM, Beetsma J (1992) Differential periods of Varroa mite invasion into worker and drone cells of honey bees. Exp \& App/ Acarol 16, 295-301

Boot WJ, Sisselaar DJA, Calis JNM, Beetsma J (1994a) Factors affecting invasion of Varroa jacobsoni (Acari: Varroidae) into honeybee, Apis mellifera (Hymenoptera, Apidae), brood celis. Bull Entomol Res 84, 3-10

Boot WJ, Beetsma J, Calis JNM (1994b) Behaviour of Varroa mites invading honey bee brood cells. Exp \& Appl Acarol 18, 371-379

Calis JNM, Boot WJ, Beetsma J (1993) Behavior of Varroa mites invading honey bee brood cells of different sizes. In: Asian apiculture (LJ Connor, T Rinderer, HA Sylvester, S Wongsiri, eds) Wicwas Press, Cheshire, CT, USA, 499-509

Fries I (1989) Short-interval treatments with formic acid for control of Varroa jacobsoni in honey bee (Apis mellifera) colonies in cold climates. Swed J Agric Res 19, 213-216

Fries I, Camazine S, Sneyd J (1994) Population dynamics of Varroa jacobsoni: a model and a review. Bee World 75, 5-28

Fuchs S (1990) Preference for drone brood cells by Varroa jacobsoni Oud in colonies of Apis mellifera carnica. Apidologie 21, 193-199

Fuchs $S$ (1992) Choice in Varroa jacobsoni Oud between honey bee drone or workerbrood celis for reproduction. Behav Ecol Sociobiol $31,429-435$

Fuchs S, Langenbach K (1989) Multiple infestation of Apis mellifera $L$ brood cells and reproduction in Varroa jacobsoni Oud. Apidologie 20, 257-266

Ifantidis MD (1988) Some aspects of the process of Varroa jacobsoni mite entrance into honey bee (Apis mellifera) brood cells. Apidologie 19, 387-396
Ifantidis MD, Rosenkranz P (1988) Reproduktion der Bienenmilbe Varroa jacobsoni (Acarina: Varroidae). Entomol Gen 14, 111-122

Le Conte Y, Arnold G, Trouiller J, Masson C, Chappe B, Ourisson $G$ (1989) Attraction of the parasitic mite Varroa to the drone larvae of honey bees by simple aliphatic esters. Science 245, 638-639

Otten C, Fuchs $S$ (1988) Individual differences in Varroa jacobsoni of preference for drone larvae to worker bee larvae. In: European Research on Varroatosis Control (R Cavalloro, ed) AA Balkema, Rotterdam, The Netherlands, 69-71

Page REJr, Metcalf RA (1984) A population investment sex ratio for the honey bee (Apis mellifera $\mathrm{L}$ ). Am Nat 124, 680-702

Rademacher E, Böttcher H, Pekel M (1989) Control of Varroatosis in Berlin (West), a region exposed to high invasion pressure. In: Present Status of Varroatosis in Europe and Progress in the Varroa Mite Control (R Cavalloro, ed) Commission of the European Communities, Luxembourg, 183-191

Rosenkranz P. Engels W (1985) Konsequente Drohnenbrutentnahme, eine wirksame biotechnische Massnahme zur Minderung von VarroatoseSchäden an Bienenvölkern. Allg Dtsche Imkerztg 19, 265-271

Rosenkranz P, Tewarson NC, Engels W (1984) Optimal host selection by reproductive female Varroa jacobsoni. In: Advances in Invertebrate Reproduction, 3 (W Engels, WHJr Clark, A Fischer, PJW Olive, DF Went, eds), Elsevier, Amsterdam, The Netherlands, 628

Rowland CM, McLellan AR (1987) Seasonal changes of drone numbers in a colony of the honeybee. Apis mellifera. Ecol Modelling 37, 155-166

Sakofski F, Koeniger N (1988) Natural transfer of Varroa jacobsoni among honeybee colonies in autumn. In: European Research on Varroatosis Control (R Cavalloro, ed) AA Balkema, Rotterdam, The Netherlands, 81-83

SAS Institute Inc (1989) SAS/STAT User's Guide, Version 6, Fourth Edition, Volume 1. SAS Institute Inc, Cary, NC, USA, 943

Schulz A, Koeniger N, Ruttner F (1983) Drohnenbrut als Varroafalle. Allg Dtsche Imkerztg 17, 52-54

Schulz AE (1984) Reproduktion und Populationsentwicklung der parasitischen Milbe Varroa jacobsoni Oud in Abhängigkeit vom Brutzyclus ihres Wirtes Apis mellifera L. Apidologie 15, 401-420

Sulimanovic D, Ruttner F, Pechhacker H (1982) Studies on the biology of reproduction in Varroa jacobsoni. Honeybee Sci 3, 109-112 (in Japanese)

Wachendörfer G, Fijalkowski J, Kaiser E, Seinsche D, Siebentritt J (1985) Labor- und Feldversuche mit der Illertisser Milbenplatte als neue Anwendungsform der Ameisensäure im Rahmen der VarroatoseBekämpfung. Apidologie 16, 291-306 